\title{
Wearable Banking: A Study of Adoption Factors in Islamic Banking Institutions
}

\author{
Hafizi Muhamad Ali \\ MS - IMT Department \\ Yanbu University College \\ Yanbu Al Sinaiyah, Saudi Arabia \\ E-mail: alih@rcyci.edu.sa
}

\author{
Rohaya Shaari \\ Management Sciences Department \\ Yanbu University College \\ Yanbu Al Sinaiyah, Saudi Arabia \\ E-mail: shaarir@rcyci.edu.sa
}

\begin{abstract}
Wearable banking has been coined by banking institutions in providing the latest technology to their customers. This study investigates the determinants which attract the Islamic banks' customers to adopt wearable banking in Malaysia. The sample size of 350 respondents has been selected from ten Islamic banks in Malaysia using the survey research instrument questionnaire. Data has been analyzed using software SPSS 15.0. The confirmatory factor analysis with multiple regressions technique has been applied. The result of regression analysis shows that Perceived Usefulness, Information of Wearable Banking, Perceived Risk, Security and Privacy shows more influence in increasing the intention of customers to adopt wearable banking services. Meanwhile, Government Support provides more influence for the bankers in adoption of wearable banking services. This study proves that bankers should emphasize more on wearable banking, since bank customers believe it is a convenient method when adopting the banks services.
\end{abstract}

Keywords-Wearable Banking, Islamic Bank, Convenience, Perceived Usefulness, Information of Wearable Banking, Perceived Risk, Security and Privacy, Government Support

\section{INTRODUCTION}

The revolution of information technology has influenced almost every part of business sectors' and people's lives in recent years. Amongst businesses directly impacted by the revolution is the banking sector. Today, the introduction of electronic banking has become more revolutionized and contribution of technology is considered to be one of the main reasons for the bank's success and for them to achieve the core competency [18].

Electronic banking is the application of information technology which helps facilitates the information and services over public standards based networks [5,9]. There are different forms of electronic banking which include; internet banking, mobile banking, telephone banking and television-banking. Electronic banking is the wider part and as such wearable banking is the specific area under electronic banking.

Wearable banking has been defined as where users can utilize different kind of facilities and services offered by the banks and the utilization of such services and facilities can be done through what they wear such as,
Google Glass and smart devices [9]. In this regards, wearable banking is considered as one of the key routes which supports the increase of usage of facilities and services in the banks. Hence, this will help increase the market share of the banks and also help develop a longterm relationship with the customers. The emergence of wearable banking was first initiated in 2013 where its growth became dominant across the globe in which Europe emerged as a leader in the practice of wearable banking [2].

Wearable banking offers many services which are beneficial for the customers [9]. Currently, some services offered from selected banks such as; follow stock market and convert currencies by CaixaBank, USA, view account balance by Nationwide, United Kingdom, basic transaction and contact customer service by Banco Sabadell, Spain, update account balance by Westpac, New Zealand, $\log$ in to account, make bill payments, conduct video call with personal banker by PrivatBank, Ukraine [22].

In Malaysia, all Islamic banks have introduced internet banking and have grown towards higher competitiveness by upgrading their technologies and services in implementing the wearable banking [14]. Therefore, the wearable banking can be adopted by most of the Islamic banks in Malaysia because of its associated vital benefits such as time and its cost effectiveness.

Previous studies have been conducted to analyze the determinants which influence the adoption of internet banking on the basis of customer's perspective independently. Nonetheless, the studies have not analyzed both the views of bank employees (bankers) and bank customers separately on their acceptance of wearable banking. This is due to the fact that bankers have more awareness on any transactions, information and the services offered by the banks compared to the customers. Therefore, the objective of this paper is to investigate the main factors which influence both the bankers and bank customers to adopt wearable banking in Malaysian Islamic banking institutions.

\section{LITERATURE REVIEW}

Since its introduction, internet banking and wearable banking has gained greater importance and priority and has been given special attention to the customers and 
employees alike which in turn supports the increases of usage of these services. Researchers have applied numerous theories to identify potential factors which influence the people to adopt wearable banking. Some of the theories include; Technology Acceptance Model (TAM), Theory of Reasoned Action (TRA) and Theory of Planned Behavior (TPB) [20,21].

As stated by Ajzen and Fishbein [4], Davis [10] and Sadeghi and Farokhian [17], Technology Acceptance Model (TAM) has been adapted from the TRA. TAM is the multivariable model that predicts the users' intentions on the basis of their perceptions, which includes five main conceptions; perceived usefulness and ease of use, intention to use, actual use and attitude to use wearable banking. As such, research model can be hypothesized on consumer behavior factors which are; service quality, relative advantage, convenience, compatibility, complexity, privacy, trust, security, attitude and belief, risks, habit, familiarity, lack of awareness, adaptability, consumer, organization, confidence, technology and computer, channels characteristics. The above-mentioned factors can directly influence the users to adopt the internet banking. Selected literatures as listed in Table I below have been reviewed to discover the impact of different factors on the adoption of internet banking for the bankers and the bank customers.

\section{TABLE I.SELECTED PREVIOUS STUDIES}

\begin{tabular}{|l|l|}
\hline Authors & \multicolumn{1}{|c|}{ Previous Studies } \\
\& Shah & $\begin{array}{l}\text { Topic:Internet banking in Malaysia: Finding } \\
\text { [1] }\end{array}$ \\
Templexities \\
diffusion Model (IDT) has to be used and the selected \\
survey sample are n=45 and the selected test is chi- \\
square Test. \\
Finding: The analysis result show 67\% of the \\
proposed complexities due to familiarity with the \\
internet technology, download speed, website design \\
unfriendly, people gaining easy access, misusing of \\
information, security, fear of government tracking \\
transactions, hinder the users in accepting internet \\
banking services. \\
Recommendation: It isrecommendedthat bank should \\
focus on the internet banking usage among its \\
customers because their costs associates are much \\
lower than traditional system.
\end{tabular}

\begin{tabular}{|l|l|}
\hline Eze, \\
Manyeki, \\
Yaw \&
\end{tabular}$\quad \begin{aligned} & \text { Topic Factors Affecting internet banking adoption } \\
& \text { among young adults: evidence from Malaysia. } \\
& \text { Techniques: Questionnaire, Factor Analysis } \\
& \text { Finding: Results shows that perceived ease of use, } \\
& \text { perceived usefulness, perceived credibility, relative } \\
& \text { advantage, trialability and self efficiency are more } \\
& \text { influence to adopt internet banking. } \\
& \text { Recommendation: It helps the banks to better } \\
& \text { understand young adults' behavior in Malaysia with } \\
& \text { respect to internet banking. This could enable banks to } \\
& \text { formulate effective techniques to attract this group to } \\
& \text { use this service. }\end{aligned}$

\section{RESEARCH METHOD}

Research model and hypothesis have been developed to gauge the most emphasizing factors which influence bankers and bank customers to adopt wearable banking in Malaysian Islamic banks. Research model is as below:

$W B=\propto+\beta_{1}(\mathrm{Con})+\beta_{2}(\mathrm{PU})+\beta_{2}(\mathrm{IWB})+\beta_{4}(\mathrm{PR})+\beta_{5}(\mathrm{SP})+\beta_{6}(\mathrm{GS})+\varepsilon$

Whereas; WB is Wearable Banking Intention, Con is Convenience, PU is Perceived Usefulness, IWB is Information Wearable Banking, GS is Government Support, PR is Perceived Risk, SP is Security and Privacy, and e is Error. Hypothesis that has been developed from the previous studies are:

$\mathrm{H}_{\mathrm{o} 1}=$ Convenience doesn't show a positive response for adoption of wearable banking.

$\mathrm{H}_{\mathrm{o} 2}=$ Perceived usefulness doesn't show a positive response for adoption of wearable banking.

$\mathrm{H}_{\mathrm{o} 3}=$ Information of wearable banking doesn't show a positive response for adoption of wearable banking. $\mathrm{H}_{04}=$ Low perceived risk doesn't show a positive response for adoption of wearable banking.

$\mathrm{H}_{\mathrm{o} 5}=$ High security and privacy doesn't show a positive response for adoption of wearable banking. 
$\mathrm{H}_{\mathrm{o} 6}=$ Government support doesn't show a positive response for adoption of wearable banking.

A questionnaire method was used to collect primary data. The adopted questionnaire involves attributes of the variables based on the prior research and is designed through Likert scale. In this study, questions are taken from prior research such as; Intention to Use as dependent variable $[14,15]$, Convenience $[10,15]$, Perceived Usefulness [12,14], Information on Wearable Banking [7], Perceived Risk [14,15], Security and Privacy $[12,15]$ and Government Support [8].

Questionnaire was randomly given to the respondents from the ten Islamic banks in Malaysia. A total of 350 completed questionnaires were returned from the bankers (100) and bank customers (250).

\section{DATA ANALYSIS AND DISCUSSION}

Factor analysis was used to analyze the main adoption factors of wearable banking from the perspective of bankers and bank customers. The factor analysis assists in reducing a large set of data into a smaller number of components that involves some associated variables [16].

A confirmatory factor analysis was performed on the basis of principle component matrix with varimax method. The Kaiser Meyer Olkin value was 0.901 for bankers and 0.899 for bank customers, which is higher than the recommended value of 0.8 which shows data sampling adequacy is good because its value is greater than 0.5. The result of Barlett's test of sphericity is significant which supports that the data is appropriate for making factor through correlation matrix [6]. The loading factors value which is higher than 0.4 is considered important and those loading value higher than 0.5 is considered practically significant [13]. In addition, all loading results of this study show significant because the values are higher than 0.5 . Cronbach's coefficient alpha $(\alpha)$ was used to measure the internal consistency of the data items. The alpha result indicates that all data items have high consistency and load considerably well on its factor. The factor analysis result is presented in Table II and III.

Multiple regression technique was applied on bankers and bank customers' data after factor analysis. Regression analysis examined whether the relationship exists between the factors for adopting wearable banking. Table III represents the regression results for bankers and Table IV displays the results for bank customers.

\section{A. Factor Analysis}

Table II below represents the bankers' factor's result that shows a total of 27 items out of original 29 loaded on 6 factors. Under factor 1 Perceived Ease of Use (PU) contains nine items after merging the two variable attributes because of correlation having $88.8 \%$ excellent reliability that measures the importance of wearable banking adoption with a variance of 53.12 percent. Factor 2 Information of Wearable Banking (IWB) contain four items having $89.5 \%$ excellent reliability and with variance of $76.17 \%$. Perceived Risk (PR) factor loaded five items having $79.10 \%$ good reliability with variance of $54.79 \%$. Another three items measuring Government Support (GS) have $68.5 \%$ good reliability with variance $61.86 \%$, while the fifth factor Security and Privacy (S and $\mathrm{P}$ ) have three items having $74.9 \%$ good reliability with variance $66.61 \%$. The sixth factor includes three items under Intention to use (INT) having $75.3 \%$ good reliability with variance of $66.98 \%$. The total variance explained by the sixth factors is $64.064 \%$.

TABLE II. ROTATED COMPONENT MATRIX OF BANKERS RESPONDENT DATA

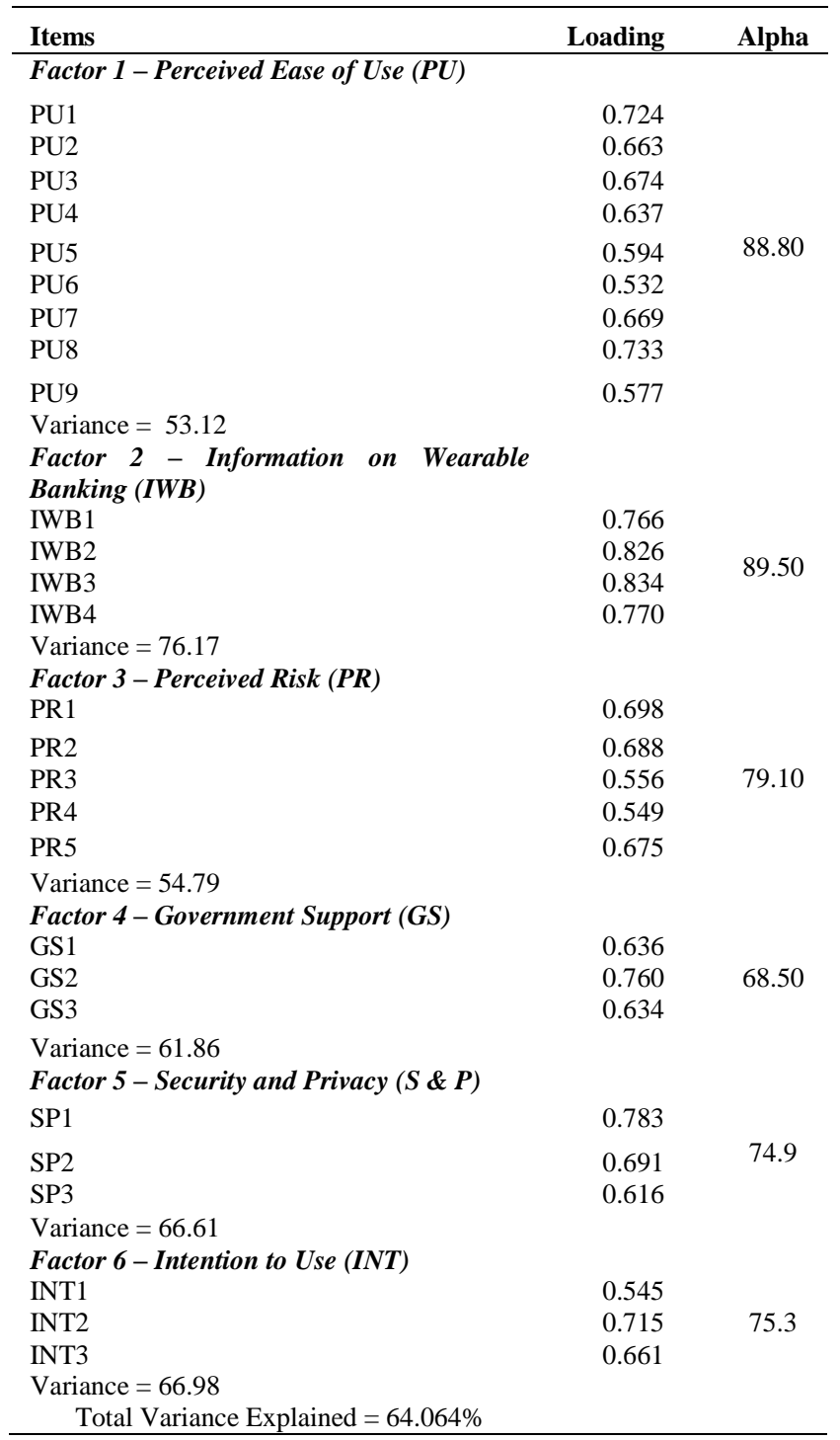

Legends for Table II:

PU1 - Wearable banking services provides helpful guidance in performing the task.

PU2 - The transactional of wearable banking is easy to use.

PU3 - Interaction with wearable banking is clear and understandable

PU4 - I find it easy to recover the error encountered while using the wearable banking services. 
PU5 - Wearable banking facilitates me to complete my banking activities quickly.

PU6 - Using wearable banking for doing banking transactions much easier.

PU7 - Wearable banking allows me to manage my finance efficiently.

PU8 - Wearable banking helps to increase customer's productivity.

PU9 - The services of wearable banking enhance the customers' effectiveness on the job.

IWB1 - Wearable banking provides believable/reliable information.

IWB2 - Wearable banking provides real time information.

IWB3 - Wearable banking provides relevant information.

IWB4 - Wearable banking provides information at the right level of details.

PR1 - The risk of credit card fraud for internet transactions and payment is low for customer.

PR2 - I would feel free to submit my financial information online because of low risk.

PR3 - By using the wearable banking services, it protects customer information privacy.

PR4 - There is a low probability to face the problem while making the internet transaction online.

PR5 - All operations through wearable banking are guaranteed.

GS1 - Government encourages and promotes the usage of internet and e-commerce.

GS2 - The government is driving the development of wearable banking.

GS3 - The government has good laws and regulations for wearable banking.

SP1 - Authorized username and password are important for securing the data.

SP2 - I trust that transaction through wearable banking is private and secure.

In Table III represents the bank customers' factor's result that shows a total of 24 items out of original 29 loaded on 6 factors. Under factor 1 Intention with Convenience (INT/CON)contains eight items after merging the two variable attributes having $92.3 \%$ excellent reliability with a variance of $65.31 \%$. According to the previous study, Intention and Convenience were considered to be separate, however, by applying confirmatory factor analysis they merged the two variables into one [15]. Factor 2 that is Information of Wearable banking (IWB) contains four items having 93.3\% excellent reliability and with variance of 83.44 percent. Perceived Usefulness (PU) factor loaded three items having $79.5 \%$ good reliability with variance of $71.43 \%$. Another three items measuring Government Support (GS) has $73 \%$ good reliability with variance $65.79 \%$. While the fifth factor Perceived Risk (PR) has three items having $84.1 \%$ excellent reliability with variance of $76.11 \%$. The sixth factor Security and Privacy (S and P) include three items which have $80.5 \%$ excellent reliability with variance of $73.42 \%$. The total variance explained by the sixth factors is $75.13 \%$.

TABLE III. ROTATED COMPONENT MATRIX OF BANK CUSTOMERRESPONDENT DATA

\begin{tabular}{|c|c|c|}
\hline Items & Loading & Alpha \\
\hline \multicolumn{3}{|l|}{$\begin{array}{l}\text { Factor } 1 \text { - Intention with Convenience } \\
\text { (INTCON) }\end{array}$} \\
\hline INTCON1 & 0.698 & \multirow{9}{*}{92.3} \\
\hline INTCON2 & 0.673 & \\
\hline INTCON3 & 0.675 & \\
\hline INTCON4 & 0.658 & \\
\hline INTCON5 & 0.734 & \\
\hline INTCON6 & 0.715 & \\
\hline INTCON7 & 0.711 & \\
\hline INTCON8 & 0.674 & \\
\hline \multicolumn{2}{|l|}{ Variance $=65.31$} & \\
\hline \multicolumn{3}{|l|}{$\begin{array}{l}\text { Factor } 2 \text { - Information of Wearable } \\
\text { banking (IWB) }\end{array}$} \\
\hline IWB1 & 0.801 & \multirow{4}{*}{93.3} \\
\hline IWB2 & 0.844 & \\
\hline IWB3 & 0.874 & \\
\hline IWB4 & 0.757 & \\
\hline \multicolumn{3}{|l|}{ Variance $=83.44$} \\
\hline \multicolumn{3}{|l|}{ Factor 3 - Perceived Usefulness $(P U)$} \\
\hline PU1 & 0.77 & \multirow{3}{*}{79.5} \\
\hline PU2 & 0.857 & \\
\hline PU3 & 0.642 & \\
\hline \multicolumn{3}{|l|}{ Variance $=71.43$} \\
\hline \multicolumn{3}{|l|}{ Factor 4 - Government Support (GS) } \\
\hline GS1 & 0.782 & \multirow{3}{*}{72.9} \\
\hline GS2 & 0.784 & \\
\hline GS3 & 0.607 & \\
\hline \multicolumn{3}{|l|}{ Variance $=65.79$} \\
\hline \multicolumn{3}{|l|}{ Factor 5 - Perceived Risk (PR) } \\
\hline PR1 & 0.816 & \multirow{3}{*}{84.0} \\
\hline PR2 & 0.595 & \\
\hline PR3 & 0.671 & \\
\hline \multicolumn{3}{|l|}{ Variance $=76.11$} \\
\hline $\begin{array}{l}\text { Factor } 6 \text { - Security and Privacy }(S \& P) \\
\text { SP1 }\end{array}$ & 0.88 & \multirow{4}{*}{80.4} \\
\hline SP2 & 0.781 & \\
\hline SP3 & 0.526 & \\
\hline \multicolumn{2}{|l|}{ Variance $=73.42$} & \\
\hline Total Variance Explained $=75.13 \%$ & & \\
\hline
\end{tabular}

Legends for Table III:

INTCON1 - I intend to use wearable banking it on a regular basis for achieving the desired future results.

INTCON2 - I intend to increase the usage of wearable banking in the future.

INTCON3 - I will robustly recommend others to use wearable banking (WB) services in daily routine transactions.

INTCON4 - Using wearable banking, I can access anytime and anywhere.

INTCON5 - The wearable banking services provides helpful guidance in performing the task.

INTCON6 - The transactional of wearable banking is easy to use.

INTCON7 - Interaction with wearable banking is clear and understandable

INTCON8 - I find it easy to recover the error encountered while using the wearable bankingservices. 
IWB1 - Wearable banking provides believable/reliable information.

IWB2 - Wearable banking provides real time information.

IWB3 - Wearable banking provides relevant information. IWB4 - Wearable banking provides information at the right level of details.

PU1 - Use of wearable banking services can save customers time.

PU2 - Wearable banking facilitates me to complete my banking activities quickly.

PU3 - Using wearable banking for doing banking transactions much easier.

GS1 - Government encourages and promotes the usage of internet and e-commerce.

GS2 - The government is driving the development of wearable banking.

GS3 - The government has good laws and regulations for wearable banking.

PR1 - The risk of credit card fraud for internet transactions and payment is low for customer.

PR2 - I would feel free to submit my financial information online because of low risk.

PR3 - By using the wearable banking services, it protects customer information privacy.

SP1 - Authorized username and password are important for securing the data.

SP2 - I trust that transaction through wearable banking is private and secure.

SP3 - I am satisfied with the security system.

\section{B. Regression Analysis}

Table IV which displays the bankers' regression analysis results shows that Perceived Ease of Use (PU), Information of Wearable Banking (IWB), Perceived Risk (PR), Security and Privacy (SP) and Government Support (GS) have significant impact to increase their intentions $(\mathrm{F}=34.657 ; \mathrm{p}$ value $=0.00)$ and the relationship exists between the variables $\mathrm{R}^{2}$ is $44.6 \%$ which shows average relationship that emphasize the bankers to adopt wearable banking. Also, the result shows that all factors are positively associated with an adoption through coefficient outcome. These results accept the proposed hypothesis.

TABLE IV. RESULTS OF MULTIPLE REGRESSION ANALYSIS OF BANKER RESPONDENT DATA

\begin{tabular}{cccc}
\hline Variables & Coefficient $\boldsymbol{\beta}$ & t-stats & Sig \\
\hline (Constant) & 0.752 & 2.531 & 0.012 \\
PU & 0.253 & 3.485 & 0.001 \\
IWB & 0.123 & 2.202 & 0.029 \\
PR & 0.147 & 2.052 & 0.041 \\
SP & 0.147 & 2.07 & 0.04 \\
GS & 0.224 & 3.484 & 0.001 \\
R & & .678 & \\
R $^{2}$ & & 0.446 & \\
F- stats & & 34.657 & \\
Sig & & 0.00 & \\
\hline
\end{tabular}

Table V below shows the bank customers' regression results which represent all variables that are significant to increase the intention by its $(F=53.674 ; p$ value $=0.00)$ and the relationship exists between the variables is moderate due to the value of $\mathrm{R}^{2}$ is 63.7 . All the factors of the model are associated positively in the adoption of wearable banking. These results accept the proposed hypothesis.

TABLE V. RESULTS OF MULTIPLE REGRESSION ANALYSIS OF BANK CUSTOMER RESPONDENT DATA

\begin{tabular}{cccc}
\hline Variables & Coefficient $\boldsymbol{\beta}$ & t-stats & Sig \\
\hline (Constant) & -0.364 & -1.245 & 0.215 \\
PU & 0.323 & 5.03 & 0.000 \\
IWB & 0.206 & 3.416 & 0.001 \\
PR & 0.159 & 2.529 & 0.013 \\
SP & 0.268 & 4.053 & 0.000 \\
GS & 0.142 & 2.186 & 0.030 \\
R & & .806 & \\
R & & 0.637 & \\
F- stats & & 53.674 & \\
Sig & & 0.00 & \\
\hline
\end{tabular}

In addition, the comparison of coefficient regression results prove which variables show more influence on the bankers and bank customers to adopt wearable banking in Malaysia. It is apparent that Perceived Usefulness (PU), Information of Wearable Banking (IWB), Perceived Risk (PR) and Security and Privacy (SP) coefficient indicate more significant impact on the intention of bank customers as compared to bankers' coefficients. Nevertheless, the Government Support (GS) coefficient shows more significant impact on the intention of bankers as compared to bank customer's coefficient.

\section{CONCLUSIONS}

This paper analyzed the adoption factors which influence the bankers and bank customers to adopt wearable banking in Islamic bank in Malaysia. Regression analysis results proved that all variables show positive relationship on the intention but Government Support (GS) shows more significant impact to the increase of the intention of bankers rather than the bank customers. Additionally, Perceived Usefulness (PU) and Information of Wearable banking (IWB), Perceived Risk (PR) and Security and Privacy (SP) show more significant impact to the increase of intention of the bank customers rather than the bankers. In this regards, bank customers rely on convenience factor as theirintentions in adopting wearable banking.

Islamic banks are therefore, recommended to focus on wearable banking as a tool to gain competitive advantages. Through these results, Islamic banks should consider the point of view of bankers and bank customers 
by analyzing the readiness of wearable devices in the market and the risk and security related issues that could be reduced by using the wearable devices. In addition, the wearable technology helps the banks increase the efficiency of work and minimize the error in the banking activities. Based on all the facts and figures obtained in this study, it isconfirmed that the use of wearable banking in Malaysia can be enlarged and expanded as their importance can be seen by their adoption. In conclusion, every successful bank in the future should rely heavily on wearable banking and manage banking activities by getting benefits through wearable banking.

\section{References}

[1] Akhlaq, M. A., and A. Shah. (2011), 'Internet banking in Malaysia: Finding Complexities', Journal of Internet Banking and Commerce (JIBC), Vol. 16 No.1, pp. 1-14.

[2] Adams, J. (2014), "Why bankers should pay attention to wearables. American Banker, Dec 2014. Retrieved http://www.ameriacnbanker.com/news/bank-technology.

[3] Amini, M. T., M. Ahmadinejad and M. J. Azizi. (2011), 'Adoption of internet banking by Iranian Customer: An Empirical Investigation', The International Journal of Management Science and Information Technology (IJMSIT), Vol. 1 No 1, pp. 47-64.

[4] Ajzen I., and Fishbein M. (1975), "Beliefs, Attitude, Intention, and Behavior: An Introduction to Theory and Research", MA, USA: Addison-Wesley.

[5] Bank Negara Malaysia. (2013), 'Annual Report 2013'. Kuala Lumpur: Bank Negara Malaysia.

[6] Bartlett, M. S. (1954), 'A further note on the multiplying factors for various X2 approximations in factor analysis'. Journal of the Royal Statistical Society, Vol. 16, pp. 296-298

[7] Chau, V. S., and L. W. NgaI. (2010), 'The youth market for internet banking services: perceptions, attitude and behaviour', Journal of Services Marketing, Vol.24 No.1, pp. 42-60.

[8] Chong, A. Y.L., K.B. Ooi B. Lin and B.I. Tan. (2010), 'Online banking adoption: an empirical analysis', International Journal of Bank Marketing, Vol.28 No.4, pp. 267-287.

[9] Crosram, P. (2014), 'Google glass still too new to interest bankers: survey', American Banker, Nov 2014.Retrieved http://www.americanbanker.com/news/bank-technology.
[10] Davis, F. D. (1989), 'Perceived Usefulness, Perceived Ease Of Use, And User Acceptance of Information Technology', MIS Quarterly, Vol.13 No.3, pp.319.

[11] Eze, U. C., L. H. Yaw J. K. Manyeki and L. C. Har. (2011), 'Factors Affecting internet banking Adoption among Young Adults: Evidence from Malaysia', International Conference on Social Science and Humanity, IPEDR, 5.

[12] Ho, C. T. B., and W.C. LiN. (2010), 'Measuring the service quality of internet banking: scale development and validation', European Business Review, Vol.22 No.1, pp.5-24.

[13] Kaiser. H. (1974), "An index of factorial simplicity." Psychometrika, Vol.39 Nol.1, pp.31-36.

[14] Kasheir, D. E., A. S. Ashour, and O. M. Yacout. (2009), 'Factors Affecting Continued Usage of internet banking Among Egyptian Customers', Communications of the IBIMA, Vol.9, pp.252-263.

[15] Nasri, W. (2011), 'Factors Influencing the Adoption of internet banking in Tunisia', International Journal of Business and Management, Vol.6 No.8, pp.143-160.

[16] Pallant, J. (2005), SPSS Survival Manual: a step by step guide to data analysis using SPSS for Windows, Version 15, 3rd Ed. Buckingham: Open University Press.

[17] Sadeghi.T. and Farokhian, s. (2011), 'The Role of Behavioral Adoption Theories in Online Banking Services', Middle-East Journal of Scientific Research, Vol.7 No. 3, pp. 374-380.

[18] Shaari, R. and Ali, H. M. (2009), 'Demographic influenves on internet banking in Malaysia, The IUP Journal of Bank Management, Vol. 8 No. 2, pp. 74-86.

[19] Shaari, R. and Ali, H.M. (2005), 'Internet banking from the perspectives of Malaysian bankers', International Journal of Management Studies, Vol. 12 No. 2, pp. 115-124.

[20] Shih, Y.-Y., \& Fang, K. (2004), The use of a decomposed theory of planned behavior to study internet banking in Taiwan. Internet Research, Vol. 14 No.3, pp. 213-223.

[21] Taylor, S., and Todd, P. A. (1995), 'Understanding Information Technology Usage: A Test of Competing Models,' Information Systems Research, Vol.6 No.2, pp. 144- 176.

[22] The Financial Brand. (2013), 'Wearbale banking: bank roll out first apps for google glass', Octpber 2013. Retrieved http://thefinancialbrand.com/34773/wearbale-banking-googleglass-applications 